\author{
Henryk Jan Botor \\ Akademia Muzyczna w Krakowie
}

\title{
Muzyka liturgiczna a nowoczesność
}

Będziemy zajmowali się muzyką liturgiczną, więc pojęcie nowoczesności dotyczyć będzie głównie muzyki. Co zatem rozumiemy przez „nowoczesność w muzyce"? W każdym okresie historii muzyki występowała tzw. nowoczesność, pewien rodzaj awangardy, ale niekoniecznie $\mathrm{w}$ takim charakterze, jaka znana nam jest z XX w. Termin „nowoczesność” w sztuce w zasadzie stosuje się do kierunków artystycznych występujących w wieku XX. Nowoczesność przejawiała się w awangardowych kierunkach, które starały się zaprzeczać i przeciwstawiać dotychczasowym tradycyjnym poglądom na sztukę, wraz z jej pięknem w tradycyjnym tego słowa znaczeniu. Zjawisko to jest typowe dla muzyki i sztuki XX w. w ogóle. Czasy obecne właściwie pozbawione są takiej awangardy. Dzisiaj, można powiedzieć, mamy okres postmodernizmu (ponowoczesności). Artyści doszli do przekonania, że kierunki występujące w XX w. się nie sprawdziły i nie przyniosły dobrych owoców, skoro ten wiek obfitował we wszelkiego rodzaju traumy, np. w postaci dwóch wojen światowych z całym ich okrucieństwem i wszelkiego rodzaju innym złem. Postmodernizm cechuje sie tym, że zapożycza pewne style z przeszłości, ale już bez wiary w to, co te kierunki reprezentowały, czyli bez ich ideologii. Zapożyczenie stylów może pochodzić z każdego wieku. Widać to zarówno w sztukach plastycznych, jak i muzycznych. Ogólnie rzecz biorąc, dzisiaj panuje właśnie taka tendencja. Z drugiej strony każdy kompozytor w swoim muzycznym języku jest indywidualistą i do tego stara sie dążyć.

Dla mnie nowoczesność w muzyce naszych czasów zaczyna się mniej więcej z początkiem ubiegłego stulecia, kiedy tonalność powoli ustępowała miejsca nowym technikom organizacji dźwięków, w związku z czym powstały różne kierunki, a także tworzyły się grupy kompozytorów, którzy swoją twórczością wyznaczali nowe trendy. W sztukach plastycznych był to stopniowy zanik rysunku (impresjonizm, ekspresjonizm) i realizmu przedstawianych postaci i przedmiotów. Awangarda drugiej połowy XX w. była swoistym rodzajem buntu. Jego wyznawcy stali się dyktatorami, próbując narzucać innym swój punkt widzenia.

Mimo tego powstały w tym czasie również utwory o wielkiej wartości, np. Pasja wedtug św. Łukasza Krzysztofa Pendereckiego. Zanim jednak zaczniemy oma- 
wiać muzykę liturgiczną, należy przypomnieć, jak doszło do tego specyficznego buntu w sztuce. ”

Sytuacja taka nastąpiła około 1918 roku, kiedy to powstał nowy kierunek artystyczny o nazwie dadaizm. Postawę artystów nierzadko cechował nihilizm, wynikający z negatywnych przeżyć podczas I wojny światowej, której byli uczestnikami. Negowali wszystko, co miało związek z pojęciem tradycyjnego piękna i tradycyjnej sztuki. Podobną postawę prezentowali np. niektórzy artyści futurystyczni. Dadaizm przerodził się w nowy kierunek - surrealizm, obejmujący tak malarstwo, jak i literaturę. Surrealizm miał już program ideologiczny, który uwzględniał m.in. wpływ podświadomości oraz marzeń sennych na twórczość artystów. Nowatorskie odkrycia Freuda miały decydujący wpływ na filozofię tego kierunku. Interesowano się wiarą ludów pierwotnych oraz buddyzmem. Eksponowano seksualizm, który przybierał formy perwersyjne. Pisemne manifesty surrealistów głosiły potrzebę pełnej emancypacji człowieka i uwolnienia go od wszelkich krępujących więzów. Stopniowo kierunek ten przybierał formę quasi-religijną, przeciwstawiając się zarazem religijności chrześcijańskiej leżącej u podstaw kultury zachodniej ${ }^{1}$.

Przedstawicielami surrealizmu w malarstwie byli min. Salvador Dali, Giorgio de Chirico, Max Ernst czy Marcel Duchamp. Teoretykiem i przewodnikiem tego nurtu był filozof i poeta André Breton. Surrealiści pisali listy otwarte do papieża, Dalajlamy czy rektorów akademickich. Treści listów zawierały m.in. krytykę postaw chrześcijańskich. Podobny bunt pojawił sie również w muzyce, ale nieco później.

Twórczość eksperymentalna współegzystuje z popularną, stanowiąc argument dla relatywizacji wartości dzieł sztuki. Historia pokazała, że żaden z nowych kierunków muzycznych nie przyjął się na dłużej, a wielu twórców po okresie buntu zaczęło wracać do korzeni, oglądając się w kierunku „bezpiecznej” przeszłości².

Postawa awangardystów jednak rzutowała na całą muzykę współczesną, co owocowało niechęcią do jej poznawania przez potencjalnych filharmonicznych słuchaczy, którzy uważali ją za trudną. Bunt w postaci awangardy zwykliśmy trak-

1 H. J. Botor, Inspiracja naturą w Koncercie na fortepian i orkiestrę Pieśni wód, opis pracy doktorskiej, Kraków 2011, s. 57-58.

2 H. J. Botor, Inspiracja naturą..., dz. cyt., s. 58. 
tować jako nowoczesność w muzyce. Wszelkie przejawy atonalności w muzyce powszechnie nazywano właśnie „współczesnością” lub „nowoczesnością”, a przecież muzyka współczesna to nie tylko atonalność oraz muzyka tworzona i wykonywana w sposób niekonwencjonalny (np. utwory sonorystyczne czy muzyka elektroniczna). Poprzez wywoływanie szoku i oryginalności za wszelką cenę muzyka współczesna bardziej się wyalienowała, stając się sztuką dla wąskiego grona słuchaczy.

Zastanówmy się, czy taka muzyka mogłaby funkcjonować w liturgii. Zanim odpowiemy na to pytanie, musimy sobie przypomnieć, jak muzyka liturgiczna się kształtowała - czy wybierała te same drogi proponowane przez kulturę. Chciałem podzielić się swoimi spostrzeżeniami oraz tym, co na ten temat pisze kard. Joseph Ratzinger w książce pt. Nowa pieśń dla Pana. Kardynał Ratzinger rzuca światło na relację między Kościołem a kulturą:

Muzyka kościelna jako wyraz wiary, który stał się elementem kultury, należy z natury rzeczy do dzisiejszej problematyki stosunku miedzy kościołem a kulturą. [...] Od końca doby Oświecenia wiara i współczesna kultura coraz bardziej się od siebie oddalały. Do tego czasu kultura, tak jak w całej historii, tak też w chrześcijańskiej Europie, wyrastała z korzeni religijnych i nawet w swoich świeckich formach wyrazu była związana z tym podłożem. Renesans i reformacja oznaczały pierwszy kryzys dla tego wzajemnego związku Kościoła i kultury, jednak dopiero w okresie Oświecenia dochodzi do właściwej rewolucji kulturalnej - do zdecydowanego wyemancypowania się kultury spod wpływu wiary. Ich drogi się rozchodzą, chociaż wiek XIX wciąż jeszcze stoi pod znakiem żywej wzajemnej wymiany ${ }^{3}$.

Kardynał Ratzinger twierdzi, że Kościół w XIX w. bardzo szybko spychany był w coś w rodzaju subkultury, która stanowiła margines wielkiego kulturowego rozwoju. Dalej pisze:

Sytuacja ta daje się zauważyć także wtedy, kiedy przyglądamy się relacji między cecyliańską reformą muzyki kościelnej a ogólną ewolucją sztuki muzycznej w 2. połowie XIX i na początku XX wieku. [...] Nie można też zaprzeczyć, że tendencja historyzująca, przejawiająca się nawrotem do dawnych stylów i więzią wiary z kulturowym wyrazem dawniejszych epok, odpowiadała również duchowi tego czasu ${ }^{4}$.

3 Kard. Joseph Ratzinger, Nowa pieśn dla Pana, przeł. J. Zychowicz, Kraków 2005, s. 150-151.

4 Kard. Joseph Ratzinger, Nowa pieśn dla Pana, dz. cyt., s. 151. 
Rozłam miedzy kulturą a muzyką stawał się coraz większy. Bardzo trafne spostrzeżenia kard. Ratzingera dotyczą czasów współczesnych. Pomimo tego, że książka została wydana w 1995 r., to jednak problem jest nadal aktualny. Kardynał pisze:

Ale również dla współczesnej kultury oderwanie od religijnego podłoża nie pozostało bez konsekwencji. Także i ona została zepchnięta na bezdroże, gdzie w coraz mniejszym stopniu potrafi odpowiedzieć na pytanie o jej własne quo vadis. We współczesnym świecie wydaje się ona jakby bezużyteczna i czyniąc z konieczności cnotę, określa sama siebie po prostu tak: sztuką jest to, co nie spełnia żadnej funkcji, lecz tylko tak sobie istnieje. W pewnym sensie to prawda, ale sama negacja nie wystarcza do tego, by zjawisku jakiegokolwiek rodzaju nadać sensowne miejsce w strukturze egzystencji człowieka i świata ${ }^{5}$.

Dalsze rozważania kard. Ratzingera prowadzą do zaskakujących wniosków:

Teraz wszakże nastąpiło coś zupełnie nowego. Muzyka uległa rozszczepieniu na dwa światy, które właściwie nie mają juz ze sobą nic wspólnego. Oto po jednej stronie znajduje się muzyka mas, która za pomocą etykiety „pop” pragnie prezentować siebie jako muzykę popularną, muzykę ludu. Muzyka stała sie tu produkowanym metodą przemysłową towarem, ocenianym według jego wartości handlowej. Z drugiej strony mamy konstruowaną według racjonalnych zasad, artystowską muzykę o maksymalnych wymaganiach technicznych, która nie jest w stanie przekroczyć wąskiego, elitarnego kręgu słuchaczy. Pośrodku między tymi dwiema skrajnościami znajdujemy ucieczkę w historię, trwanie w muzyce, która istniała przed tym podziałem, przemawiała i dziś jeszcze potrafi przemawiać do całego człowieka. Łatwo się domyślić, że muzyka kościelna sytuuje się przeważnie w tym obszarze środkowym. Ponieważ jednak Kościół żyje w obecnym czasie, nie mógł nie spróbować swych sił również w obu przeciwstawnych przestrzeniach współczesnej kulturowej schizofrenii. Kiedy dzisiaj słusznie domagamy się nowego dialogu między Kościołem a kulturą, to nie można przy tym zapominać, że dialog ten musi być dwustronny. Nie może polegać na tym, że Kościół podporządkuje się ostatecznie współczesnej kulturze, która od kiedy utraciła swoją religijną podstawę, żyje w znacznej mierze w stanie samozwątpienia ${ }^{6}$.

5 Kard. Joseph Ratzinger, Nowa pieśń dla Pana, dz. cyt., s. 151-152.

6 Kard. Joseph Ratzinger, Nowa pieśn dla Pana, dz. cyt., s. 152-153. 
Ekspansja muzyki popularnej zaczęła się od Elvisa Presleya, który był swoistym fenomenem kulturowym na skalę wcześniej niespotykaną. Później powstawały inne zespoły rockowe, które w tekstach swoich piosenek niejednokrotnie preferowały satanizm. W nagrania wmontowywano przesłania podprogowe, tzn. teksty satanistyczne zapisane na bardzo wysokich lub niskich częstotliwościach dźwięku. Były niezauważalne dla słuchacza, ale bez problemu wychwytywane przez mózg i zapisywane w pamięci.

Dotykając problemu muzyki liturgicznej w obecnych czasach, musimy sobie uświadomić, w jakim świecie ona powstaje i na co jest narażona. Wiek XX można by nazwać wiekiem buntu człowieka przeciwko Bogu i wszelkim autorytetom. Nie pozostaje to bez wpływu na sztukę, a nawet na muzykę, której próbuje się używać w liturgii. Analizując muzykę, a zwłaszcza muzykę liturgiczną, musimy sobie uświadomić, że, jak mówi instrukcja o liturgii Musicam sacram, przyczynia się ona do większej chwały Boga oraz do uświęcenia wiernych ${ }^{7}$. Jest to ważna wskazówka, którą powinniśmy się kierować, wykonując lub komponując muzykę liturgiczną, ale musimy sobie uświadomić to, że służąc w świątyni i dla liturgii, jesteśmy wystawieni, może jeszcze bardziej niż inni, na zagrożenia duchowe. Warto sięgnąć do homilii ojca świętego Pawła VI z 29 czerwca 1972 r.:

W obliczu sytuacji Kościoła współczesnego odnosimy wrażenie, że swąd szatana przedostał się pewnymi szczelinami do Ludu Bożego. Widzimy zwątpienie, niepewność, relatywizm, niepokój, niezadowolenie i kwestionowanie. Nie mamy już zaufania do Kościoła, ufamy natomiast pierwszemu lepszemu prorokowi świeckiemu, który przemawia do nas ze szpalt któregoś z dzienników czy jako rzecznik jednego z ruchów społecznych [...], nie zastanawiając się nad tym, że jesteśmy już przecież w posiadaniu [...] prawdziwego Życia, że jesteśmy jego panami. [...] Jak mogło dojść do tego? Wmieszała się w to przeciwstawna moc, której na imię diabeł: ów tajemniczy byt, o którym wspomina w swym liście św. Piotr (1 P 4, 8-9). [...] Wierzymy w działanie szatana, które dokonuje się dziś w świecie, właśnie po to, by wprowadzać zamęt, by niszczyć owoce soboru i by przeszkadzać Kościołowi wyśpiewywać swą radość z powodu odzyskania pełnej samoświadomości ${ }^{8}$.

Po tej wypowiedzi Paweł VI został mocno zaatakowany przez media światowe.

7 Por. Instrukcja o muzyce w świętej liturgii Musicam Sacram, pkt 4.

8 R. Laurentin, Szatan mit czy rzeczywistość, przeł. T. Szafrański, Warszawa 1997, s. 224. 
W XX w. nastąpił znaczny rozłam między kulturą a Kościołem, pomiędzy którymi konieczny jest przecież aktywny dialog. Jak jednak powiedział kard. Ratzinger - dialog musi być obustronny. Trudno przecież adaptować do liturgii pewne wzorce muzyczne, które z wiarą i Bogiem nie mają nic wspólnego. Przez niektórych artystów muzyka kościelna postrzegana jest jako coś, co jest mało artystyczne, może czasem prymitywne, amatorskie. Być może dlatego, że „szanujący się” kompozytor nie chce „zniżyć się” do prostych melodii, które mogłyby służyć „prostaczkom" (?). Nie bez wpływu na taką opinię pozostaje zatrudnianie jako organistów ludzi niekompetentnych, amatorów, osób bez kwalifikacji muzycznych, którzy robią wiernym więcej szkody niż pożytku. Na przestrzeni wieków Kościół zatrudniał przecież często wybitnych muzyków i kompozytorów, którzy na stałe wpisali się w historię muzyki liturgicznej. Ich utwory mogły wynieść wiernych na wyżyny piękna, które to piękno swoje korzenie zawsze posiada w Bogu.

Należy uświadomić sobie, że muzyka tworzona w wiekach poprzednich zawsze była muzyką im współczesną i taki stan właściwie przetrwał aż do XIX w. Sytuacja się zmieniła w XX w., kiedy pojawiało się coraz więcej różnych stylów muzycznych. Pomimo tego, iż można dziś wyróżnić pewne wspólne kierunki wówczas występujące, to jednak język kompozytorów stawał się coraz bardziej zindywidualizowany. Jeśli chodzi o muzykę rozrywkową, stała się ona wszechobecna, czy tego chcemy, czy nie (np. w domach towarowych). Ze szkół zniknęły lekcje śpiewu, w mediach muzyka klasyczna praktycznie nie istnieje, oprócz stacji jej poświeconych. Muzyka organowa pojawia się tylko w filmach animowanych dla dzieci jako ilustracja złych postaci! Jak zatem w takiej sytuacji ma funkcjonować muzyka liturgiczna, gdy dzieci straszy sie organami? Jak wierni mają się utożsamiać z muzyką liturgiczną, chorałem gregoriańskim, jeśli bombardowani są zewsząd wzorcami komercyjnymi? Nie bez powodu kard. Ratzinger nazwał współczesne czasy „kulturową schizofrenią". Dla niektórych wiernych przychodzących do Kościoła msza święta to jedyna okazja, aby obcować z prawdziwym pięknem, które w dodatku służy Bogu. Czy tak jest powszechnie? Młodzież potrzebuje gitary, bo nie utożsamia się już z tzw. klasyką czy chorałem gregoriańskim. Są to negatywne owoce komercjalizacji. Jak zatem dziś powinna funkcjonować muzyka liturgiczna? Czy współczesne wzorce muzyczne można stosować w liturgii, mając na myśli zarówno klasykę, jak i rozrywkę?

\section{Zanik poczucia scıcrum}

Czy każdą muzykę można wykonywać podczas liturgii? Przyzwyczailiśmy się do tego, że w kościele wszystko można, a szczególnie można wykonywać każdą muzykę. Nie wszystko jednak, co nam się podoba, jest odpowiednie dla przestrzeni 
świątyni. Zdarza się, że wiernym proponuje się muzykę liturgiczną przystosowaną do ich percepcji i w rezultacie muzyka ta niejednokrotnie przyjmuje charakter niezgodny z duchem liturgii. Czasami poruszam ten problem z moimi studentami. Jeden z nich powiedział, że stosując muzykę bardziej przystępną, o charakterze rozrywkowym czy jazzowym, i z umiarem dodając do tego perkusję, możemy zachęcić do przyjścia na mszę świętą większą liczbę ludzi. Czy tak jest naprawdę? Mam pewne wątpliwości, choć poziom muzyczny niewątpliwie odgrywa w percepcji wiernych dużą rolę. $\mathrm{Na}$ zarzuty stosowania perkusji itp. słyszy się zdania, że „w Afryce murzyni w kościele tańczą”. To prawda, ale nikt się nie zastanawia nad tym, że w pewnych kulturach taniec służy również modlitwie i jest wyrazem głębokich uczuć, a nie jest tylko elementem rozrywki, często o zabarwieniu erotycznym, jak to bywa u nas. Kardynał Joseph Ratzinger zwraca uwagę zarówno na „słowo” w muzyce liturgicznej, jak i na charakter samej muzyki: „słuszne jest jednak zdanie, że muzyka, która służy oddawaniu czci Bogu w Duchu i prawdzie, nie może być rytmiczną ekstazą, zmysłową sugestią czy odurzeniem, subiektywną czułostkowością, powierzchowną rozrywką, lecz jest przyporządkowana pewnemu orędziu, rozległej duchowej i w najwyższym sensie rozumowej wypowiedzi. Inaczej mówiąc, słuszne jest zdanie, że winna ona temu stowu w szerokim znaczeniu od wewnątrz odpowiadać, a nawet służyć"’.

W świątyni wszystko powinno być inne, począwszy od architektury, malarstwa, rzeźby, a na muzyce kończąc. Zauważmy, że np. w średniowiecznych katedrach, a nawet w większych kościołach wspaniale rzeźbione portale symbolizowały bramę niebios. Przechodząc przez nie do wnętrza świątyni, człowiek znajdował się jakby w innym świecie! Ogarniała go inna przestrzeń, inne światło, mistyczny klimat, a wreszcie inna muzyka.

\section{Jan Pawet II List do artystów - pojęcie piękna}

Wobec tej „kulturowej schizofrenii”, jak nazwał owo zjawisko kard. Ratzinger, człowiek może się pogubić. Z jednej strony jest bombardowany przez kulturę „pop”, a z drugiej spotyka się z innym pojęciem piękna i jego wartości niż kiedyś. Człowiek przyjął różne punkty widzenia na wartość sztuki i jej sens. Zaczął sam decydować o jej wartości, niezależnie od tego, jak to czyniono kiedyś, i niezależnie od kryteriów, jakimi kierowano się dawniej.

W atmosferze tej „kulturowej schizofrenii” powstał jednak bardzo ważny dokument, napisany przez św. Jana Pawła II, a jest nim List do artystów. To ważny drogowskaz dla tych, którzy rzeczywiście poszukują prawdziwego piękna w swo-

9 Kard. J. Ratzinger, Nowa pieśń dla Pana, dz. cyt., s. 190. 
jej sztuce. Jest on też drogowskazem dla kompozytorów, którzy tworzą muzykę sakralną, ale też liturgiczną. Ojciec święty Jan Paweł II przypomniał, że mamy do czynienia także z innym nurtem w sztuce:

Ale jest też prawdą, że w epoce nowożytnej obok tego nurtu humanizmu chrześcijańskiego, nadal tworzącego wybitne dzieła kultury i sztuki, stopniowo ukształtowała się też inna forma humanizmu, którą cechuje nieobecność Boga, a często nawet sprzeciw wobec Boga. [...] Jak jednak wiecie, Kościół nadal żywi bardzo wysokie uznanie dla sztuki jako takiej. Sztuka bowiem, jeżeli jest autentyczna, choć niekoniecznie wyraża się w formach typowo religijnych, zachowuje więź wewnętrznego pokrewieństwa ze światem wiary, tak że nawet w sytuacji głębokiego rozłamu miedzy kulturą a Kościołem właśnie sztuka pozostaje swego rodzaju pomostem prowadzącym do doświadczenia religijnego ${ }^{10}$.

Jan Paweł II akcentuje też postawę Soboru Watykańskiego II wobec relacji między Kościołem a kulturą, cytując fragment Przestania do artystów z 1965 r.: „Świat, w którym żyjemy, potrzebuje piękna, aby nie pogrążyć się w rozpaczy. Piękno podobnie jak prawda budzi radość w ludzkich sercach i jest cennym owocem, który trwa mimo upływu czasu, tworząc więź między pokoleniami, i łączy je w jednomyślnym podziwie"11.

Jan Paweł II nie neguje przejawów nowoczesności w sztuce - wyraża swój szacunek dla tych, którzy poszukują nowych środków wyrazu, ale też wskazuje na to, aby nadać sens tym poszukiwaniom. Do artystów całego świata zwraca się w ten sposób:

Kieruję do was wezwanie, byście na nowo odkryli głęboki wymiar duchowy i religijny sztuki, który w każdej epoce znamionował jej najwznioślejsze dzieła. W tej perspektywie apeluję do was, artyści słowa pisanego i mówionego, teatru, muzyki i sztuk plastycznych, twórcy wykorzystujący najnowocześniejsze środki wyrazu. Zwracam się zwłaszcza do was, artyści chrześcijańscy: każdemu z was pragnę przypomnieć, że przymierze istniejące od zawsze między Ewangelią a sztuką, niezależnie od swoich aspektów funkcjonalnych, wiąże się z wezwaniem do wniknięcia twórczą intuicją w głąb tajemnicy Boga Wcielonego, a zarazem w tajemnicę człowieka ${ }^{12}$.

Jan Paweł II akcentuje też, aby powołanie artysty było oddane w służbie pięknu. Cytuje przy tym wielkiego poetę polskiego Cypriana Kamila Norwida:

10 Jan Paweł II, List do artystów, pkt 10.

11 Jan Paweł II, List do artystów, dz. cyt., pkt 11.

12 Jan Paweł II, List do artystów, dz. cyt., pkt 14. 
Bo piękno na to jest, by zachwycało

Do pracy - praca, by się zmartwychwstało.

Trudno bardziej trafnie określić, czym jest piękno. W dzisiejszym świecie niektórzy artyści wstydzą się ujawniać fascynację pięknem w tradycyjnym jego pojęciu. Niektórzy artyści drugiej połowy XX w. wydawali się skorumpowani powszechnie panującym trendem w sztuce, gdzie po prostu nie wypadało mieć innych poglądów od ogólnie społecznie narzuconych. Niektórzy jednak po latach przyznali się do takiej postawy.

We wspomnianym już Liście do artystów Jan Paweł II zwraca uwagę na powiązanie piękna z dobrem: „Relacja miedzy dobrem a pięknem skłania do refleksji. Piękno jest bowiem poniekąd widzialnością dobra, tak jak dobro jest metafizycznym warunkiem piękna" ${ }^{13}$.

\section{Techniki kompozytorskie w XX w. i możliwości ich stosowania w liturgii}

W poprzednich wiekach muzyka liturgiczna naznaczona była współczesnością, czyli ogólnie panującą wówczas estetyką. Jak już wspomniałem, wykonywano prawie wyłącznie muzykę współczesną. Nie sposób pomylić Mszę Bacha czy Mozarta z Mszą Pucciniego, gdyż są to trzy różne estetyki muzyczne, pomimo tego, że wszystkie posiadają ten sam tekst mszalny. Ciekaw jestem, jak by wyglądała np. Msza Johna Cage’a, ze wszystkimi jego nowymi, nierzadko komicznymi, pomysłami muzycznymi. Wobec tak wielkiej różnorodności stylów, jakie powstały w XX w., nie da sie jednoznacznie wskazać kierunku, który stanowiłby odpowiednie sacrum w liturgii. Generalnie nowoczesna muzyka XX w. w swoim brzmieniu emanowała modną wówczas dużą dysonansowością, a co się z tym wiązało - tragizmem, dramatem i niepokojem. Było to całkowicie przeciwstawne charakterowi chorału gregoriańskiego. Charakter tej muzyki był obcy bywalcom filharmonii, a co dopiero wiernym w kościele. Nie ma się co dziwić, że muzyka ta nie mogła na stałe zagościć w kościele. Nawet nowy modalizm genialnego Oliviera Messiaena nie był powszechnie akceptowany w St. Trinite w Paryżu, gdzie Messiaen był organistą. Swoją muzykę mógł on wykonywać tylko na jednej z mszy niedzielnych, o godzinie 12.00 , reszta mszy świętych musiała pozostać muzycznie tradycyjna ${ }^{14}$. Messiaen z powodzeniem również improwizował, ale nie zawsze wolno mu było

13 Jan Paweł II, List do artystów, dz. cyt., pkt 3.

14 Por. T. Kaczyński, Messiaen, Kraków 1984, s. 104. 
to robić we własnym stylu, gdyż pieśń, przed którą improwizował, wymagała jednak zachowania tego samego stylu ${ }^{15}$.

W moim przekonaniu techniki kompozytorskie $\mathrm{XX}$ w. należy stosować $\mathrm{z}$ wielką rozwagą i krytycyzmem oraz wielkim poczuciem „dramatyzmu” liturgicznego. Myślę, że najbardziej odpowiednie miejsca to Preludium przed rozpoczęciem mszy świętej, ewentualna improwizacja na ofiarowanie, na dziękczynienie oraz Postludium na zakończenie mszy świętej. Wykonując improwizacje czy kompozycje, zapożyczając elementy z jakiegoś języka kompozytorskiego XX w., nie powinniśmy go stosować do tradycyjnych śpiewów kapłana. Ich brzmienie jest wyjątkowo sakralne i nie powinno tego zabraknąć. Dobrym tego przykładem są msze święte odprawiane w katedrze Notre-Dame w Paryżu, gdzie w grze organowej łączone są różne style. Przy pomocy nowoczesnych środków wyrazu można by śmiało stworzyć np. ilustrację organową do tekstu Pasji czytanej w Niedzielę Palmową, jak uczynił to kiedyś prof. Julian Gembalski w katowickiej Archikatedrze Chrystusa Króla. Wydaje mi się, że jest to jedyna okazja w całym roku liturgicznym, kiedy można sobie pozwolić na większą dysonansowość muzyczną, a co za tym idzie - większy dramatyzm. Okres Wielkiego Postu predysponowany jest do tego typu brzmień, choć oczywiście wszystko należy czynić z umiarem, gdyż organy w Wielkim Poście powinny częściej milczeć. Od początku XX w. powstały takie kierunki kompozytorskie jak: impresjonizm, ekspresjonizm, witalizm, dodekafonia, neoklasycyzm, serializm, punktualizm, bruityzm, muzyka konkretna, aleatoryzm, nowy modalizm (Messiaen), muzyka stochastyczna (m.in. Iannis Xenakis), muzyka mikrotonowa (Alois Haba, Andrzej Panufnik), sonoryzm (m.in. Krzysztof Penderecki), happening - teatr instrumentalny (Maurizio Kagel, Bogusław Schaeffer), minimal music (Steve Reich, Zygmunt Krauze, Wojciech Kilar, Henryk Mikołaj Górecki), spektralizm (Gerard Grisey, Tristan Murail) czy postmodernizm. Widzimy, jak ten czas jest bardzo różnorodny w muzyce. Sądzę, że najciekawsze do improwizacji liturgicznych są te kierunki, które rozwijają harmonikę oraz prezentują nowe skale, a więc na pewno częściowo impresjonizm z jego paralelizmem harmonicznym, ekspresjonizm, witalizm oraz zdobycze nowego modalizmu Messiaena. Wzory neoklasycystyczne, a nawet sonorystyczne są dobrym materiałem do tworzenia improwizacji. Godna polecenia jest też tzw. minimal music (muzyka repetytywna). $\mathrm{Na}$ jej bazie można tworzyć wspaniałe kontemplacyjne preludia na dziękczynienie.

Takie kierunki jak bruityzm, czyli nurt inpirowany techniką i przemysłem XX w., oraz muzyka konkretna, elektroniczna czy muzyka spektralna nie są brane pod uwagę ze względu na daleko idące eksperymentowanie z dźwiękiem, który staje się tutaj celem. Dotyczy to również happeningu i teatru instrumentalnego.

15 T. Kaczyński, Messiaen, dz. cyt. 
Osobiście nie jestem przeciwnikiem eksperymentowania oraz szukania nowych brzmień, ale wydaje mi sę, że msza święta nie jest odpowiednim miejscem do tego rodzaju przedsięwzięć. Muzyka używana w liturgii musi być sprawdzona, aby nie zakłócała czynności liturgicznych, tylko mogła się z nimi zespolić. Poza tym, jak już wspomniałem, jej brzmienie musi emanować sakralnością tak, aby nie sposób jej pomylić z muzyką nieliturgiczną. Jest to zadanie trudne dla twórców, gdyż nowoczesna muzyka kojarzy się właściwie wyłącznie z eksperymentem. To od kompozytorów oraz organistów-improwizatorów zależy kształt muzyki liturgicznej. To oni, używając ewentualnych współczesnych technik kompozytorskich, mają stworzyć sacrum. Jest to zadanie niełatwe i bardzo odpowiedzialne. Ktoś może powiedzieć, że to niemożliwe, ale to po owocach poznaje się, czy coś jest właściwe czy nie.

\section{Streszczenie}

\section{Muzyka liturgiczna a nowoczesność}

W każdej muzycznej epoce pojawiał się pewien rodzaj nowoczesności, który powodował rozwój muzycznego języka. Jednak nowoczesność pojmowana współcześnie rozpoczęła się mniej więcej na początku wieku XX w., szczególnie w malarstwie. Zapoczątkował ją kierunek malarski zwany dadaizmem. Artyści, którzy go tworzyli, nierzadko kierowali się nihilizmem. Dadaizm przerodził się w nowy kierunek, zwany surrealizmem. Jego przedstawicielami byli m.in. Salvador Dali, Giorgio de Chirico, Max Ernst, Marcel Duchamp. Kierunek ten cechował się też buntem artystów przeciwko tradycyjnemu pojęciu piękna i sztuki.

Podobny bunt $\mathrm{w}$ muzyce nastąpił dopiero na przełomie lat pięćdziesiątych i sześćdziesiątych XX w., w postaci tendencji awangardowych, co spowodowało rozpad tradycyjnego podejścia do tworzenia muzyki. Muzyka liturgiczna w tym czasie zachowała swój tradycyjny język muzyczny, a to zaowocowało większym rozdźwiękiem między Kościołem a kulturą. Kardynał Joseph Ratzinger w swojej książce Nowa pieśn dla Pana porusza i analizuje te zjawiska, przez co książka ta jest znakomitą pozycją pomocną w rozwiązywaniu tych problemów.

Znakomitym drogowskazem dla twórców nie tylko muzyki liturgicznej jest List do artystów św. Jana Pawła II, w którym autor porusza sens twórczości. List ten jest też pewnym pomostem między twórcą sztuki współczesnej a Kościołem.

Można również próbować stosować pewne współczesne techniki kompozytorskie w liturgii, ze szczególnym uwzględnieniem tych, które dotyczą harmonii i skal muzycz- 
nych (np. skale Messiaenowskie). Jednakże należy czynić to z rozwagą, aby nie zakłócić przeżywania liturgii przez wiernych.

\section{Summary}

\section{Liturgical music and modernity}

In every music age there occurred a certain kind of modernity which brought about the development of musical language. However, modernity as understood these days occurred more or less at the beginning of the $20^{\text {th }}$ century, particularly in painting. It was initiated by the painting movement known as Dadaism. The artists who created this movement often followed nihilism. Dadaism turned into a new movement called surrealism. Its representatives were, among others, Salvador Dali, Giorgio de Chirico, Max Ernst, Marcel Duchamp. This movement was also characterised by artists' rebellion against the traditional conception of beauty and art.

A similar rebellion in music did not follow until the end of the 1950s in the form of avant-garde tendencies, which brought about the breakdown of the traditional approach to music creation. At that time liturgical music maintained its traditional musical language, which showed results in the form of a bigger disintegration of the church and culture. In his book $A$ song for the Lord Cardinal Joseph Ratzinger raises and analyses these phenomena, which makes the book a splendid title to solve those problems.

An excellent lodestar for the authors of not only liturgical music is $A$ letter to artists by saint John Paul II, in which the author raises the sense of artistic work. The letter is also a kind of a bridge between the creator of contemporary art and the church.

One may also try applying certain modern composer techniques in liturgy, with particular consideration of the ones that concern concertina and musical scales (e.g. Messiaen scales). However, it should be done very carefully so as not to disturb experiencing liturgy by the faithful.

Tłumaczenie: Katarzyna Haberka

Stowa kluczowe: muzyka liturgiczna, współczesne techniki kompozytorskie, Jan Paweł II, kard. Joseph Ratzinger

Keywords: liturgical music, contemporary composing techniques, John Paul II, card. Joseph Ratzinger 


\section{Bibliografia}

Botor H. J., Inspiracja naturą w Koncercie na fortepian i orkiestrę Pieśni wód, opis pracy doktorskiej, Kraków 2011.

Jan Paweł II, List do artystów.

Kaczyński T., Messiaen, Kraków 1984.

Laurentin R., Szatan mit czy rzeczywistość, przeł. T. Szafrański, Warszawa 1997.

Ratzinger J., Nowa pieśń dla Pana, przeł. J. Zychowicz, Kraków 2005. 